\title{
Masting effect on alpha and beta avian diversity in fragmented forests of relict-endangered Mexican Beech (Fagus grandifolia subsp. mexicana)
}

Ernesto C. Rodríguez-Ramírez ${ }^{1}$, Levinn Camacho-Islas ${ }^{1}$, Ana Paola Martínez-Falcón², Isolda Luna-Vega ${ }^{1}$ and Pilar Carbó-Ramírez ${ }^{3,4^{*}}$ (1)

\begin{abstract}
Background: Tropical montane cloud forests are one of the most important hotspots on Earth and show presence of relict-endemic and endangered species, representing about 14\% of the total tropical forest worldwide. Synchronous seed production or masting in tropical montane cloud tree species is a widespread reproductive strategy of deciduous and evergreen broad-leaved tree associations to decrease costs of reproduction and ensure offspring. Masting event maintains a high avian diversity, which can be modified by phenological process (seed production and nonseed production).
\end{abstract}

Methods: The main aim of this study was to assess alpha and beta avian diversity and whether the composition of the trophic guild modifies among phenological processes and between two fragmented relict-endangered Mexican Beech (Fagus grandifolia subsp. mexicana) forests (Medio Monte and El Gosco) in the Mexican state of Hidalgo. In addition, we evaluated beechnut production.

Results: We recorded 36 bird species, 11 of them included in some conservation risk status, and 5 endemic species. Alpha diversity values were dissimilar in avian richness $(q=0)$ among phenological processes and between fragmented beech forests. Avian communities among three phenological processes and between fragmented forests were structurally similar, dominated during immature seeds the Brown-backed Solitaire (granivores-insectivoresfrugivores); during mature seeds the White-crowned Parrot (Pionus senilis, granivores-frugivores); and the Dwarf Jay (Cyanolyca nana, insectivores) was abundant during low seed quality. The complementarity index was high among phenological processes and low between forests. We found a high bird turnover value between immature seedsmature seeds and during mature seeds - low seed quality. Furthermore, a similar pattern was recorded between the two study forests. Seed production showed a high number of undamaged beechnuts in Medio Monte, while in El Gosco beechnuts were attacked by insects.

Conclusions: Our results reflect that masting phenological process and contrasting study forests'structure influence the shifts in alpha and beta diversity of seed and non-seed bird consumers. Our study reaffirms the importance of continuing studies throughout masting in all the Mexican Beech forests to address regional efforts in preserving the relict-ecological interactions.

*Correspondence: pilarcarbo18@gmail.com

${ }^{3}$ Centro de Investigaciones Biológicas, Universidad Autónoma de Estado de Hidalgo, Hidalgo, Mexico

Full list of author information is available at the end of the article original author(s) and the source, provide a link to the Creative Commons licence, and indicate if changes were made. The images or other third party material in this article are included in the article's Creative Commons licence, unless indicated otherwise in a credit line to the material. If material is not included in the article's Creative Commons licence and your intended use is not permitted by statutory regulation or exceeds the permitted use, you will need to obtain permission directly from the copyright holder. To view a copy of this licence, visit http://creativecommons.org/licenses/by/4.0/. The Creative Commons Public Domain Dedication waiver (http://creativeco mmons.org/publicdomain/zero/1.0/) applies to the data made available in this article, unless otherwise stated in a credit line to the data. 
Keywords: Avian seed consumers, Bird species, Synchronous seed production, Tropical montane cloud forest, Turnover, Zentrygon albifacies

\section{Background}

Tropical montane cloud forests (TMCFs) are one of the most important hotspots on Earth due to the presence of relict-endemic and endangered species (Ponce-Reyes et al. 2012; Hu and Riveros-Iregui 2016; Rahbek et al. 2019). TMCF represent about $14 \%$ of the total tropical forest worldwide (Mulligan 2010), principally found in Asia, North and South American and Africa, comprising varied structures, floristic affinities, and very diverse species composition (Roman et al. 2010; Toledo-Aceves et al. 2011). This type of vegetation is characterized by the frequent presence of fog and/or drizzle causes persistent moisture (60-85\%) throughout the year (Gual-Díaz and Rendón-Correa 2014), and usually thrives on steep slope ravines $\left(>30^{\circ}\right)$ with specific microenvironmental features (e.g. moisture, soil type, $\mathrm{pH}$, among others) (RodríguezRamírez et al. 2018a). The Mexican TMCF shows a high diversity of tree species (e.g. Liquidambar, Quercus, Fagus, Magnolia, Pinus, Podocarpus, Clethra, Meliosma, Tilia, Carpinus, Nyssa, Ostrya, Acer, Alnus, Symplocos and Prunus; Luna-Vega et al. 2000; Toledo-Aceves et al. 2011 ); unfortunately, it currently covers $<1 \%$, and faces a drastic reduction in area (over $50 \%$ ) caused by logging to clear areas for pasture, crop fields or avocado, corn and/ or coffee plantations (Muñoz-Villers and López-Blanco 2008; Gual-Díaz and Rendón-Correa 2014).

The TMFC has a pronounced seasonality (e.g. fog, rainfall, moisture and temperature) that influences phenological patterns such as seed production or masting (Kelly 1994; Pearse et al. 2016) which in turn affects seed dispersal/or predation by mammals and birds (Jensen 1985). Nevertheless, drastic climate fluctuations, habitat fragmentation and isolation create unprecedented pressures, causing irregular seed production (Godínez-Ibarra et al. 2007).

Birds are dispersal agents that are a key in the functionality and process (i.e. synchronic seed production) of forest ecosystems (Jansen et al. 2004; Amico and Aizen 2005; Zaccagnini et al. 2011; Fletcher 2015) by influencing population dynamics, social structure and disease prevalence (Martínez-Morales 2007; Navarro-Sigüenza et al. 2014). Different bird species, notwithstanding, respond negatively or positively to fragmentation, anthropic activities and/or land-use, affecting ecosystem networks (Martínez-Morales 2005; Hagen et al. 2012; Rueda-Hernandez et al. 2015).

In the TMCFs, avian communities occur with a high degree of habitat specialization and many species have low dispersal capacity, making this a habitat of ecological importance for avian conservation (e.g. Dendrortyx barbatus, Zentrygon albifacies, Cyanolyca nana; Martínez-Morales 2007). Studies of Mexican TMCF avian communities have found contrasting species richness and high species turnover among fragments (RuedaHernandez et al. 2015, state of Veracruz; CalderónPatrón et al. 2016, state of Hidalgo). Another study in Mexican Beech forests in Hidalgo (a vegetation type associated with the TMCF) reported that during masting, several seed bird consumers were observed (Ehnis 1981). Nevertheless, it is necessary to explore how avian structure (e.g. richness, abundance and evenness) and composition (e.g. identity of species) respond to changes in plant associations with restricted distribution and dramatic seed production behavior through masting year (i.e. synchronic seed production and nonseed production).

Mexican Beech (Fagus grandifolia subsp. mexicana (Martínez) A. E. Murray) is a relict-endemic tree species, which is dominant and a common representative of small TMCF fragments (1-42.5 ha) in the Sierra Madre Oriental in eastern Mexico found between 1400 and $2000 \mathrm{~m}$ a.s.l., mainly on ravine slopes $\left(43.8^{\circ}\right)$ (WilliamsLinera et al. 2003; Téllez-Valdés et al. 2006). Mexican Beech is characterized by synchronic seed production (at 2- to 8-year intervals; Ehnis 1981; Rodríguez-Ramírez et al. 2018a). This strategy favors the fitness of plants and economizes the cost of reproduction (the predator satiation hypothesis; Bogdziewicz et al. 2020).

Fagus is a genus distributed in North America, Europe and Asia. Several studies associated with specific beech forests [e.g. Fagus grandifolia Ehrn in USA (Darley-Hill and Johnson 1981; Rosemier and Flaspohler 2006), F. sylvatica L. in Europe (Perdeck et al. 2000; Kardell 2005; Chamberlain et al. 2007), and F. crenata Blume in Japan (Yui 1991; Yasaka et al. 2003)] reported that beechnuts are an important resource of the diet of several bird species. Meanwhile, the studies emphasize the importance of local (e.g. vegetation structure, anthropic activities) and landscape-scale (e.g. fragmentation, edge effect) variables as factors that negatively influence bird species richness (Martínez-Morales 2005; Wells et al. 2011).

In Europe, high avian turnover was associated with the Common Beech (F. sylvatica) related forest attributes and microclimatic conditions (Mentil et al. 2018). In addition, Grendelmeier et al. (2019) found that the mast seeding in the Common Beech may influence bird abundance 
directly (seed consumers) and indirectly (non-seed consumers), which affects ecological interactions.

In this study, we provided the first assessment of alpha and beta avian diversity (during a masting year, 2017) and how bird diversity and the composition of trophic guilds modifies during three phenological processes: (1) immature seeds (IS; June-July); (2) mature seeds (MS; August); and (3) low seed quality (LQ; September) in two fragmented Mexican Beech forests. Therefore, we hypothesized that the phenological process given for the changes during the masting event and between the study forests by contrasting degree of fragmentation may affect the alpha, beta avian diversity, and the composition of trophic guilds. Furthermore, according to MartínezMorales (2007), bird communities are still unexplored in our study forests, so we provide valuable new information. In addition, we estimated beechnut production during a masting event and compared between fragmented forests to complement the characterization of the phenological process of this relict-endemic type of vegetation.

\section{Methods}

\section{Study forests}

We studied two isolated and fragmented Mexican Beech forests in the state of Hidalgo (Fig. 1) which are considered the largest and genetically heterogeneous beech forests in Mexico, according to Pérez-Rodríguez (1999). This type of vegetation occurs under restricted climatic conditions within the TMCF, located in the Sierra Madre Oriental (Téllez-Valdés et al. 2006). Our

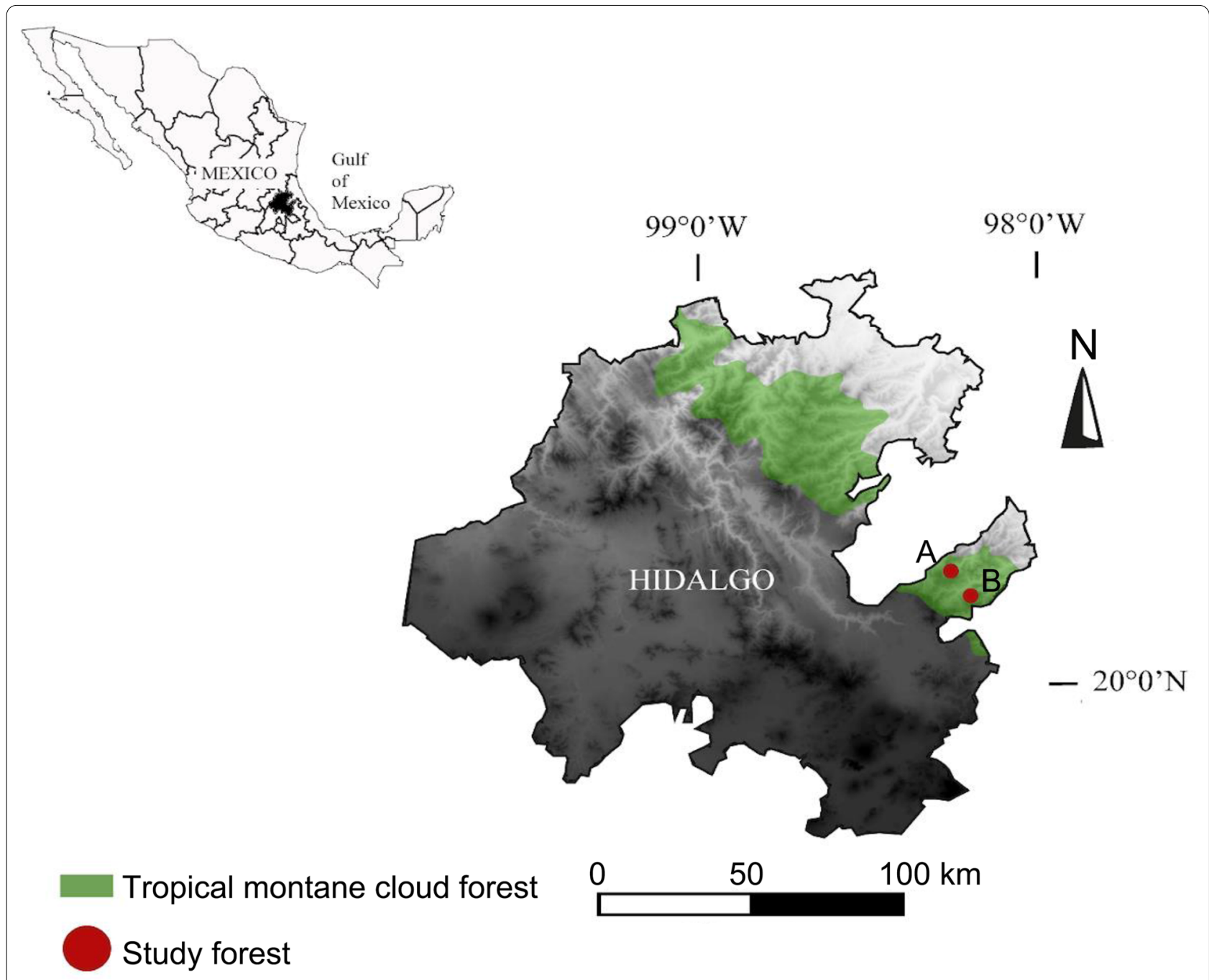

Fig. 1 Geographical location of the two isolated fragments of Mexican Beech forests studied in the Tropical montane cloud forests of the Sierra Madre Oriental, Hidalgo, in eastern Mexico. A= Medio Monte and B=El Gosco 
two localities were separated by $15.58 \mathrm{~km}$ and presented the following characteristics:

1) The locality of Medio Monte in the municipality of San Bartolo Tutotepec $\left(20^{\circ} 24^{\prime} 50^{\prime \prime} \mathrm{N}\right.$, $98^{\circ} 14^{\prime} 24^{\prime \prime} \mathrm{W}$ at $1800-1944 \mathrm{~m}$ a.s.l.) is one of least disturbed and largest fragment Mexican Beech forest $(34.25 \mathrm{ha})$, located in the northwestern part of the municipality surrounded by steep montane ravines. This study forest has a temperate climate (Cwb; Kottek et al. 2006; Peel et al. 2007) with mild temperatures (14.5 to $24.2{ }^{\circ} \mathrm{C}$ ) and annual precipitation between 1200 and $2000 \mathrm{~mm}$ (RodríguezRamírez et al. 2018b). Medio Monte is characterized by trees reaching up to $25 \mathrm{~m}$ in height, with a canopy dominated by Mexican Beech, Patula Pine (Pinus patula Schltdl. \& Cham.), Mountain Magnolia or Yoloxóchitl (Magnolia schiedeana Schltdl.) and Red Oak (Quercus meavei S. Valencia-A., Sabás \& O.J. Soto). The mid-canopy is composed of Mexican Clethra (Clethra mexicana DC.), White Oaks (Q. delgadoana S. Valencia, Nixon \& L.M. Kelly, Q. trinitatis Trel.), whereas the low canopy consists mainly of two tree ferns species: Cyathea fulva (M. Martens \& Galeotti) Fée and Dicksonia sellowiana var. arachneosa Sodiro (Rodríguez-Ramírez et al. 2018b).

2) The locality of El Gosco in the municipality of Tenango de Doria $\left(20^{\circ} 19^{\prime} 37.8^{\prime \prime} \mathrm{N}, 98^{\circ} 14^{\prime} 57.1^{\prime \prime} \mathrm{W}\right.$ at 1557-1864 $\mathrm{m}$ a.s.l.) is the smallest and most fragmented Mexican Beech forest (4.5 ha) located in the western part of the municipality surrounded by montane slope ravines. This study forest has been mainly disturbed by illegal logging (RodríguezRamírez et al. 2013). The climate is temperate (Cwb; Kottek et al. 2006; Peel et al. 2007) with an average annual temperature of $17^{\circ} \mathrm{C}$ and an annual precipitation of $1733 \mathrm{~mm}$ with $<60 \mathrm{~mm}$ rainfall rates per month (Rodríguez-Ramírez et al. 2019). In the study forest, the high canopy $(\geq 20 \mathrm{~m})$ is composed of Mexican Beech, Patula Pine, White Oak, Sweetgum (Liquidambar styraciflua L.), Tarflower (Befaria aestuans L.), and Mountain Magnolia. The mid-canopy (10 to $20 \mathrm{~m}$ ) is dominated by Neotropical tree species, such as Zapotillo (Sideroxylon portoricense subsp. minutiflorum (Pittier) T.D. Penn.), Sabino (Podocarpus reichei J. T. Buchholz \& N.E. Gray), Sweetwood (Nectandra salicifolia (Kunth) Nees) and Wild Avocado (Beilschmiedia mexicana (Mez) Kosterm) (RodríguezRamírez et al. 2018b).

\section{Beechnut production}

We characterized and described the three phenological events in each study forest by assessing the beechnut production in three phenological processes: immature seeds (IS), empty or contains an undeveloped embryo; mature seeds (MS), presence of well-developed embryo; and low seed quality (LQ), presence of empty seeds or infested by fungi (Fig. 2). In each process, we collected, counted and classified beechnuts monthly in four categories: (1) undamaged; (2) attacked by insects (i.e. typical oviposition marks or with larvae); (3) empty (by the endosperm absence); and (4) immature (according to Godínez-Ibarra et al. 2007). The beechnuts or seeds (1.5 $\mathrm{cm}$ in length) are involved by a spiny, four-valvate cupule (RodríguezRamírez et al. 2016).

We selected 30 mature Mexican dominant beech trees (i.e. with a diameter at breast height $\geq 40 \mathrm{~cm}$ at $1.5 \mathrm{~m}$ from the trunk (Rodríguez-Ramírez et al. 2018b) in each study forest. The distance between individual trees was approximately $10 \mathrm{~m}$, which is far enough to ensure seed production data independence (Rodríguez-Ramírez et al. 2018b). After mass flowering began (May), we placed 30 circular seed traps in each study forest. Each trap (1 $\mathrm{m}^{2}$ in surface area) consisted of a plastic funnel that was attached to a PVC tube with a diameter of $5.08 \mathrm{~cm}$ and a height of $1 \mathrm{~m}$ to avoid seed removal by mammals and birds (the main predators in the study forests) after seed drop. The beechnut data obtained from the traps were reported by percentage.

\section{Avian surveys}

At each study forest, we carried out one survey during each phenological process (from June to September) in a masting year (2017). Each study forest was visited once in the morning ( $1 \mathrm{~h}$ after dawn) and once in the evening ( $2 \mathrm{~h}$ before sunset) to standardize the daily avian species fluctuation to guarantee a high completeness of inventory. To register avian diversity exclusive to the Mexican Beech forest, we followed two complementary survey methods (Olvera-Vital et al. 2020) due to distinctive features of sites, like steep-slope montane ravines and closed canopy (>90\%; Rodríguez-Ramírez et al. 2013):

1) We located seven transects $(250 \mathrm{~m} \times 10 \mathrm{~m})$ in each fragmented forest, which walked slowly for 10 to $15 \mathrm{~min}$, and all birds seen or heard were recorded. 2) Also, seven $25 \mathrm{~m}$-radius point counts were located at each forest; minimum distance from point to point was $250 \mathrm{~m}$ to ensure data independence, and birds were recorded for 15 min (modified by Ralph et al. 1996). We used avian field guides for identifying species (Peterson and Edward 1989; Howell and Webb 1995; National Geographic Society 2006; van Perlo 2006). The residence status of avian 


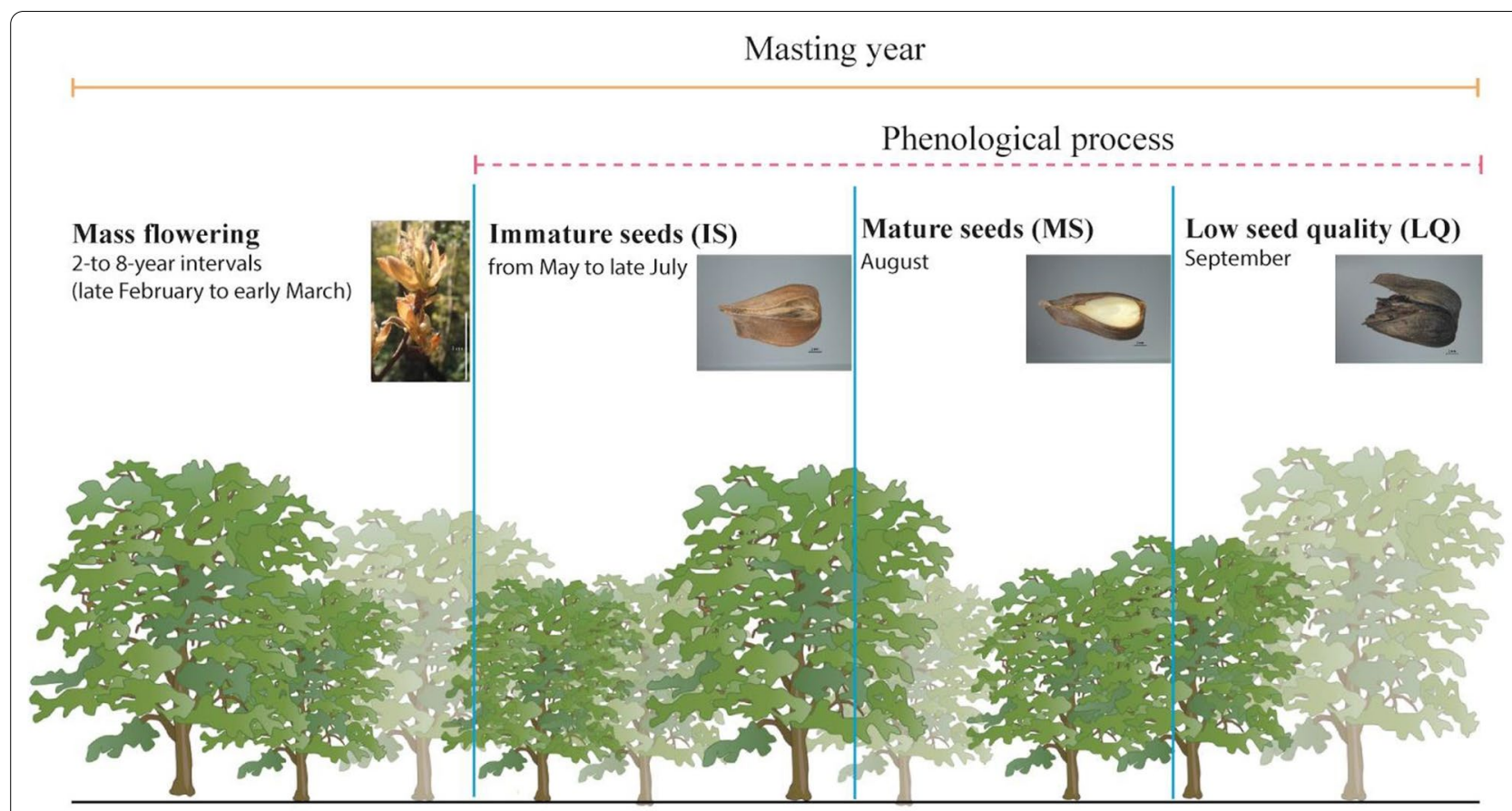

Fig. 2 Description of phenological process during a Mexican Beech masting event

species was classified according to Martínez-Morales (2007), and trophic guilds were based on foraging behavior (Howell and Webb 1995; Billerman et al. 2020) as well as personal observations during fieldwork.

\section{Data analyses \\ Alpha diversity}

We used the sample coverage estimator suggested by Chao and Jost (2012), with values from 0 (minimal completeness) to $100 \%$ (maximum completeness) to evaluate avian survey effort considering individuals. Alpha avian diversity was calculated using the indices $q=0$ that represents species richness, and $q=1$ which represents the exponential value of the Shannon index that considers species and their abundances (ecological diversity; Hill 1973). These analyses were performed among three phenological processes and between fragmented forests.

For a given diversity order $q$, the alpha diversity is:

$$
q_{D}=\left(\sum_{i=1}^{S} p_{i}^{q}\right)^{1 /(1-q)}
$$

where $S$ is the number of species, $p_{i}$ is the relative abundance of species $i$, and $q$ is the order number of diversity. Different values of $q$ correspond to different ecological diversity indices; $q=0$ corresponds to species richness, which places the maximum weight on rare species (abundances are ignored), and $q=1$ corresponds to algebraic transformations of the Shannon index of diversity. As $q$ increases, the Hill number index is increasingly weighted by the relative abundances of common species (Jost 2006). These values were compared using 95\% confidence intervals. We used the iNEXT R library (Chao et al. 2014; R Core Team 2018) to compute the analytical solutions for Hill's numbers $q=0$ and 1 .

We used rank-abundance curves to assess the structure of avian assemblages and to compare among three phenological processes and between fragmented forests (Magurran 2004). We also compared differences in avian composition among three phenological processes (IS, MS and LQ) and between fragmented forests (Medio Monte and El Gosco) by building Bray-Curtis similarity matrices. We performed a PERMANOVA analysis to assess the similarity of residual values after 999 permutations under the reduced model (Clarke 1993). We performed a non-metric multidimensional scaling (NMDS) to show avian compositional differences and how they are modified through phenological process and between fragmented forests. NMDS ordinations were based on Bray-Curtis distances and 30 randomizations to determine the most stable solution. We used the stress-plot function and the Stress index to assess the values of the ordination. These analyses were performed in R software using the R-package vegan (Oksanen et al. 2019). 


\section{Beta diversity}

We calculated the complementarity index described by Colwell and Coddington (1994). The index varies from zero (when the lists are identical) to unity (when the lists are completely distinct); also, could be expressed as the percentage of species from 0 to $100 \%$. To represent shared and exclusive avian species among three phenological processes and between fragmented forests were performed Venn diagrams.

We partitioned beta diversity following the procedure of Podani and Schemera (2011) based on the approach of Baselga (2010). According to this method, total dissimilarity $\left(\beta_{\mathrm{cc}}\right)$ is 1 minus the similarity coefficient of Jaccard. The $\beta_{\mathrm{cc}}$ is divided into two components: turnover $\left(\beta_{.3}\right.$, replacement of one species by another) and nestedness ( $\beta_{\text {rich }}$, differences in species richness). This partition was developed for analyzing the dissimilarity in avian composition between phenological process (IS and MS, MS and LQ, IS and LQ) and between fragmented forests (Medio
Monte and El Gosco). These analyses were performed in R software (R Core Team 2018), using the R-script of Carvalho et al. $(2012,2013)$.

\section{Results}

\section{Seed production}

We found empty and immature beechnuts (100\%) during IS in both fragmented forests. During MS, Medio Monte registered mostly undamaged seeds (85\%) and only $15 \%$ were empty, while El Gosco registered a large amount of empty seeds (89\%), a few seeds attacked by insects $(9 \%)$ and a low proportion of seeds were immature (2\%). During LQ, both forests registered empty seeds ( $48 \%$ for Medio Monte and 20\% for El Gosco), while the rest were infested by fungi (Fig. 3).

\section{Avian surveys}

We registered 36 species from 20 families and 33 genera (Table 1). Of them, $83 \%$ were residents, $8 \%$ presented

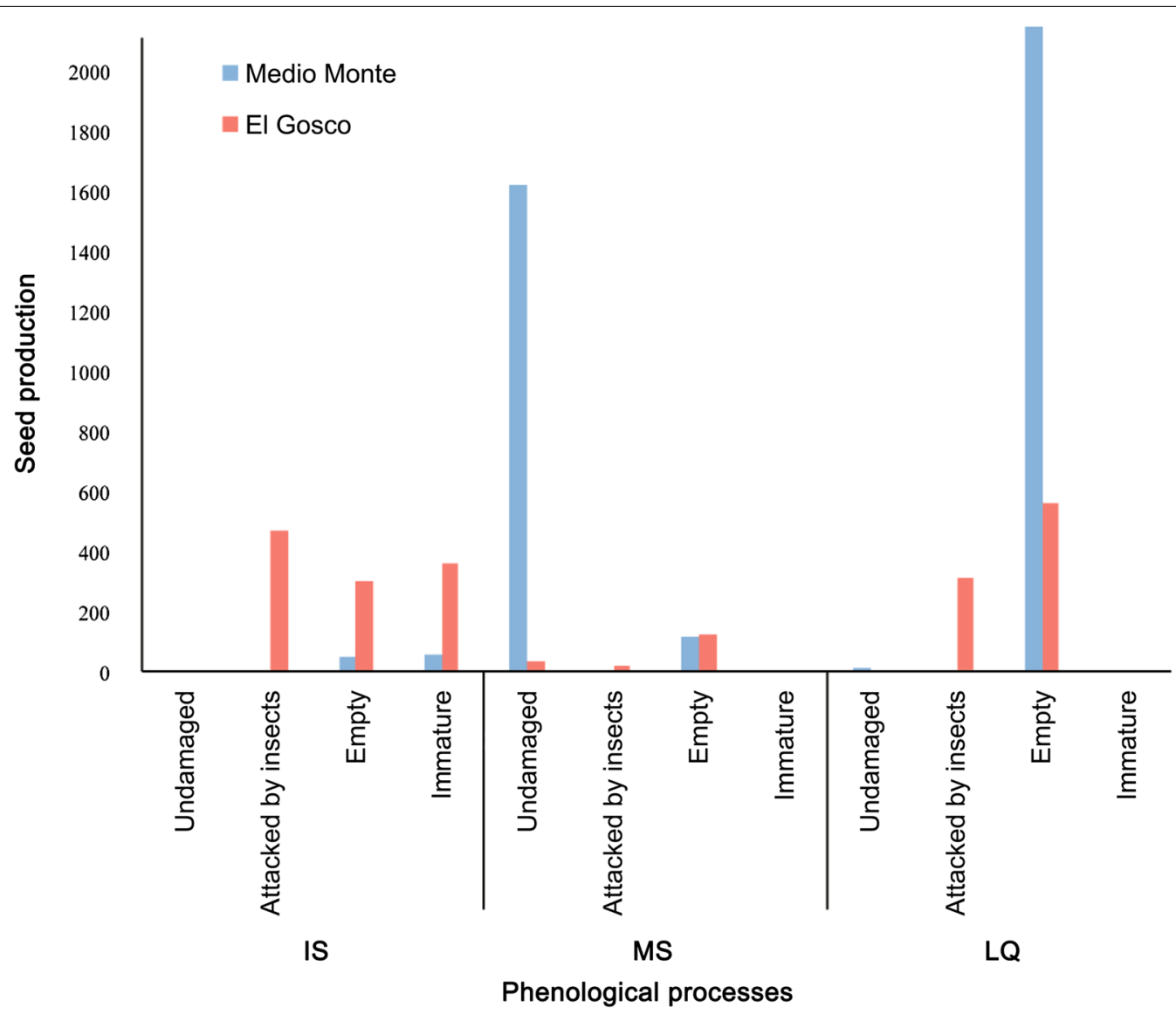

Fig. 3 Beechnut production among three phenological processes (IS, MS and LQ) and between Mexican Beech forests (IS=immature seeds; $M S=$ mature seeds; $L Q=$ low seed quality. The explanations apply also to Figs. 4, 5, 6, 7, 8) 
Table 1 Bird species recorded during three phenological processes in Mexican Beech forests

\begin{tabular}{|c|c|c|c|c|c|c|c|c|}
\hline Family & Species & Trophic group & IS & MS & LQ & $\begin{array}{l}\text { Medio } \\
\text { Monte (N) }\end{array}$ & El Gosco (N) & $\begin{array}{l}\text { Residence } \\
\text { status }\end{array}$ \\
\hline Odontophoridae & Dendrortyx barbatus ${ }^{\text {a* }}$ & $G, F, I$ & & $x$ & $x$ & 2 & 1 & $\mathrm{R}$ \\
\hline Columbidae & Zentrygon albifacies** & $\mathrm{G}, \mathrm{F}$ & & $x$ & & 7 & 4 & $\mathrm{R}$ \\
\hline \multirow[t]{4}{*}{ Trochilidae } & Lampornis amethystinus & N & $x$ & & & 211 & 0 & $\mathrm{R}$ \\
\hline & Lamprolaimarhami* & N & $x$ & & & 0 & 2 & $\mathrm{R}$ \\
\hline & Amazilia cyanocephala & N & $x$ & & & 0 & 2 & $\mathrm{R}$ \\
\hline & Hylocharis leucotis & N & $x$ & & & 0 & 4 & $\mathrm{R}$ \\
\hline Strigidae & Aegolius acadicus & $C$ & $x$ & & & 3 & 0 & $\mathrm{R}$ \\
\hline \multirow[t]{2}{*}{ Trogonidae } & Trogon caligatus & $F_{1} I$ & $x$ & & & 0 & 1 & $\mathrm{R}$ \\
\hline & Trogon mexicanus & $F_{1} I$ & $x$ & $x$ & $x$ & 26 & 6 & $\mathrm{R}$ \\
\hline Ramphastidae & Aulacorhynchus prasinus*** & $F_{1} I$ & & $x$ & & 4 & 2 & R \\
\hline \multirow[t]{3}{*}{ Picidae } & Melanerpes formicivorus & $F, I$ & $x$ & $x$ & $x$ & 23 & 2 & $\mathrm{R}$ \\
\hline & Picoides fumigatus & 1 & $x$ & $x$ & & 122 & 1 & R \\
\hline & Colaptes auratus & । & & & $x$ & 0 & 1 & R \\
\hline Psittacidae & Pionus senilis ${ }^{\mathrm{a} * *}$ & $\mathrm{G}, \mathrm{F}$ & & $x$ & & 12 & 0 & $\mathrm{R}$ \\
\hline \multirow[t]{2}{*}{ Furnariidae } & Sclerurus mexicanus** & I & & & $x$ & 2 & 0 & $\mathrm{R}$ \\
\hline & Xiphorhynchus erythropygius** & । & $x$ & & $x$ & 0 & 2 & $\mathrm{R}$ \\
\hline \multirow[t]{3}{*}{ Tyrannidae } & Empidonaxsp. & & & $x$ & & 0 & 1 & - \\
\hline & Empidonax occidentalis ${ }^{b}$ & I & $x$ & $x$ & & 1 & 1 & R \\
\hline & Empidonax fulvifrons & । & & $x$ & & 1 & 0 & $\mathrm{R}$ \\
\hline Vireonidae & Vireoleucophrys & । & & & $x$ & 1 & 1 & $\mathrm{R}$ \\
\hline Corvidae & Cyanolyca nana ${ }^{a *}$ & । & & & $x$ & 4 & 0 & R \\
\hline Certhiidae & Certhia americana ${ }^{a *}$ & । & & $x$ & & 3 & 0 & $\mathrm{R}$ \\
\hline \multirow[t]{2}{*}{ Throglodytidae } & Troglodytes aedon & । & $x$ & & & 1 & 0 & $R, M$ \\
\hline & Hernicorhina leucophrys & । & $x$ & & & 2 & 0 & $\mathrm{R}$ \\
\hline Polioptilidae & Poliotila caerulea & 1 & $x$ & & & 2 & 0 & $R, M$ \\
\hline \multirow[t]{4}{*}{ Turdidae } & Myadestes occidentalis*** & $G, I, F$ & $x$ & $x$ & $x$ & 33 & 11 & $\mathrm{R}$ \\
\hline & Catharus aurantiirostris & $G, I, F$ & $x$ & & & 2 & 0 & $\mathrm{R}$ \\
\hline & Catharus guttatus & $\mathrm{O}$ & $x$ & $x$ & & 2 & 2 & M \\
\hline & Turdus migratorius & $F_{1} I$ & $x$ & $x$ & & 6 & 1 & $R, M$ \\
\hline Mimidae & Melanotis caerulescens ${ }^{\mathrm{a}}$ & $\mathrm{O}$ & $x$ & & & 2 & 0 & R \\
\hline Fringillidae & Euphonia elegantissima & $\mathrm{F}$ & & $x$ & & 1 & 0 & $\mathrm{R}$ \\
\hline \multirow[t]{3}{*}{ Parulidae } & Setophaga dominica & । & & & $x$ & 1 & 0 & M \\
\hline & Basileuterus belli & 1 & $x$ & & & 3 & 0 & $\mathrm{R}$ \\
\hline & Myioborus pictus & 1 & $x$ & & & 1 & 22 & $\mathrm{R}$ \\
\hline \multirow[t]{3}{*}{ Cardinalidae } & Piranga leucoptera & $F, I$ & $x$ & & $x$ & 0 & 3 & $\mathrm{R}$ \\
\hline & Habia fuscicauda & $\mathrm{G}, \mathrm{I}, \mathrm{F}$ & $x$ & & & 1 & 0 & $\mathrm{R}$ \\
\hline & Passerina ciris ${ }^{* * *}$ & $\mathrm{G}, \mathrm{I}, \mathrm{F}$ & $x$ & & & 2 & 0 & T \\
\hline
\end{tabular}

IS, immature seeds; MS, mature seeds; and LQ, low seed quality; Presence $(\mathrm{X})$ and relative abundance $(\mathrm{N})$ are reported. Bird nomenclature follows the American Ornithological Society (Chesser et al. 2019). Trophic guild: F, frugivore; G, granivore; I, insectivore; N, nectarivore; O, omnivore; C, carnivore. Residence status: R, breeding resident; $M$, winter migrant; $T$, transient

Endemism: ${ }^{a}$ endemic to Mexico and ${ }^{b}$ restricted distribution

Endangered species according to NOM-059 (SEMARNAT 2010)

* Endangered; **Threatened; and ${ }^{* * *}$ Special Protection

resident and migratory populations, $6 \%$ were classified as migratory and $3 \%$ were transient; we did not determine the status of one individual that was not identified at the species level (Table 1). Eleven species are included in some threatened status by Mexican laws (SEMARNAT
2010; Table 1). Five species are endemic to Mexico and one is restricted to Mexico, the United States and Canada (Martínez-Morales 2007) (Table 1).

All bird species registered in each fragmented forest were previously reported for the state of Hidalgo 
(Martínez-Morales 2007). Also, we confirmed the presence of the Garnet-throated Hummingbird (Lamprolaima rhami), previously considered hypothetical for Hidalgo, and we report the first record of the Northern Saw-whet Owl (Aegolius acadicus) in the TMCF in Hidalgo, previously reported for oak and pine forests (Martínez-Morales 2007). The bird species represent nine trophic guilds: $42 \%$ of the species are insectivores, $16 \%$ frugivores-insectivores, $11 \%$ granivores-insectivores-frugivores, $11 \%$ nectarivores, $5 \%$ granivores-frugivores, $5 \%$ omnivores, $3 \%$ frugivores, $3 \%$ carnivores, and $3 \%$ granivores-frugivores-insectivores (Table 1).

Avian communities among three phenological processes were structurally similar, dominated by few bird species. For example, during IS the Brown-backed Solitaire (Myadestes occidentalis, granivores-insectivoresfrugivores), the Mountain Trogon (Trogon mexicanus, frugivores-insectivores) and the Acorn Woodpecker (Melanerpes formicivorus, frugivores-insectivores) were the most abundant avian species, while the Whitecrowned Parrot (Pionus senilis, granivores-frugivores), the White-faced Quail-Dove (Zentrygon albifacies, granivores-frugivores) and the Brown-backed Solitaire were abundant during MS, and the Dwarf Jay (Cyanolyca nana, insectivores) was abundant during LQ process (Fig. 4a; Table 1). We found a similar pattern between fragmented forests, where the Brown-backed Solitaire and Mountain Trogon were the most abundant (Fig. 4b).

\section{Alpha diversity}

The completeness of the avian inventory was greater than $80 \%$ in the three phenological processes and between fragmented forests (Table 2). Higher avian richness was
Table 2 Hill's numbers $(q=0, q=1)$, confident interval (Cl), and sample coverage values $(\mathrm{Sc})$ of avian communities among three phenological processes and between Mexican Beech forests

\begin{tabular}{llllll}
\hline & $\mathbf{q = 0}$ & $\mathbf{C l}$ & $\mathbf{q = 1}$ & $\mathbf{C l}$ & $\mathbf{S c}$ \\
\hline Study forest & & & & & \\
El Gosco & 19 & 3.48 & 13.8 & 3.52 & 0.83 \\
Medio Monte & 29 & 3.53 & 14.11 & 2.64 & 0.94 \\
Phenological process & & & & & \\
IS & 24 & 4.07 & 10.09 & 2.39 & 0.93 \\
MS & 15 & 1.71 & 10.16 & 1.2 & 0.88 \\
LQ & 11 & 2.36 & 10 & 2.33 & 0.82 \\
El Gosco & & & & & \\
IS & 10 & 2.81 & 7.67 & 2.7 & 0.8 \\
MS & 7 & 1.93 & 6.3 & 1.7 & 0.88 \\
LQ & 7 & 1.97 & 6.61 & 2.11 & 0.49 \\
IS & 10 & 7.67 & 7.67 & 2.7 & 0.8 \\
MS & 7 & 6.3 & 6.3 & 1.7 & 0.88 \\
Medio Monte & & & & & \\
IS & 17 & 2.81 & 7.89 & 1.68 & 0.96 \\
MS & 13 & 3.8 & 8.99 & 2.73 & 0.86 \\
LQ & 7 & 2.76 & 5.85 & 3.02 & 0.56 \\
IS & 17 & 2.81 & 7.89 & 1.68 & 0.96 \\
MS & 13 & 3.8 & 8.99 & 2.73 & 0.86 \\
\hline IS, & & & &
\end{tabular}

IS, immature seeds; MS, mature seeds; and LQ, low seed quality

recorded during IS followed by MS and the lowest richness during the LQ process $(q=0$; Fig. $5 \mathrm{a})$. Medio Monte showed a higher avian richness than El Gosco $(q=0$; Fig. 5b; Table 2). Ecological diversity (richness and abundance, $q=1$ ) did not differ among three phenological processes (Fig. 5c; Table 2) and between fragmented forests
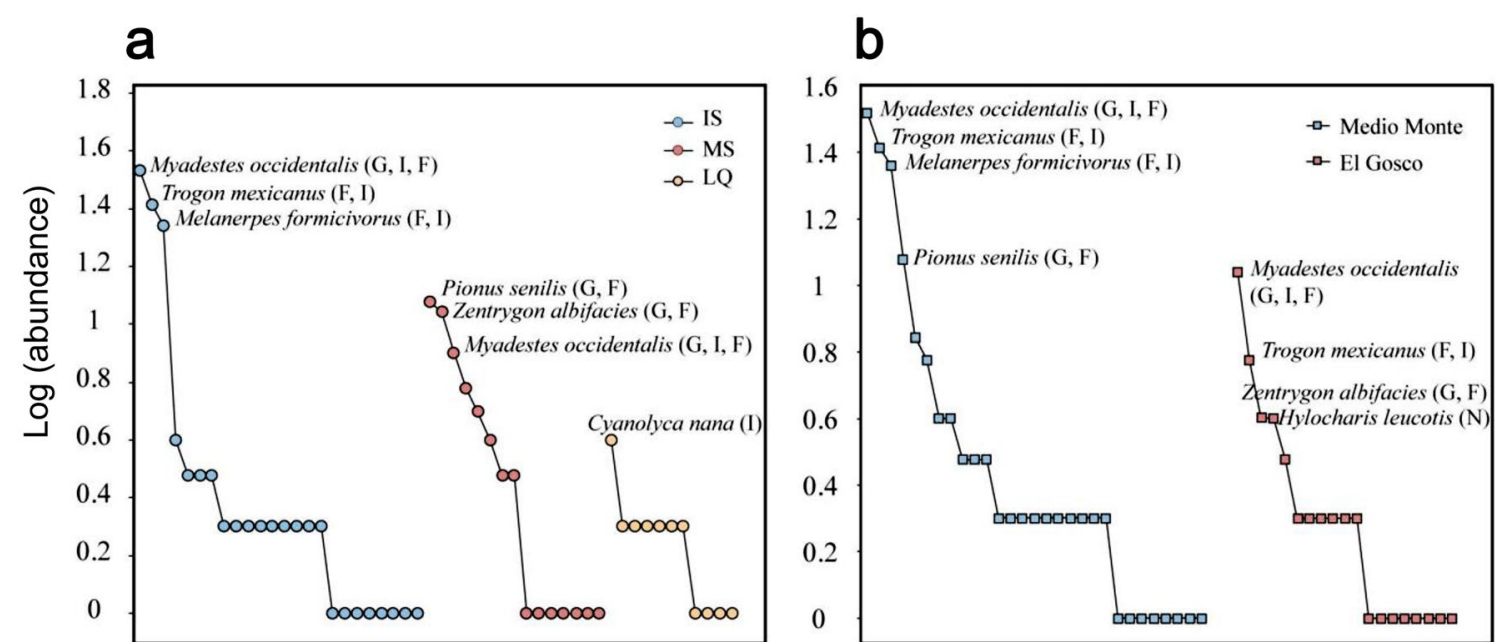

Fig. 4 Rank-abundance curves. (a) Bird communities among three phenological processes and (b) bird communities between fragmented forests. Trophic guilds codes are in Table 1 


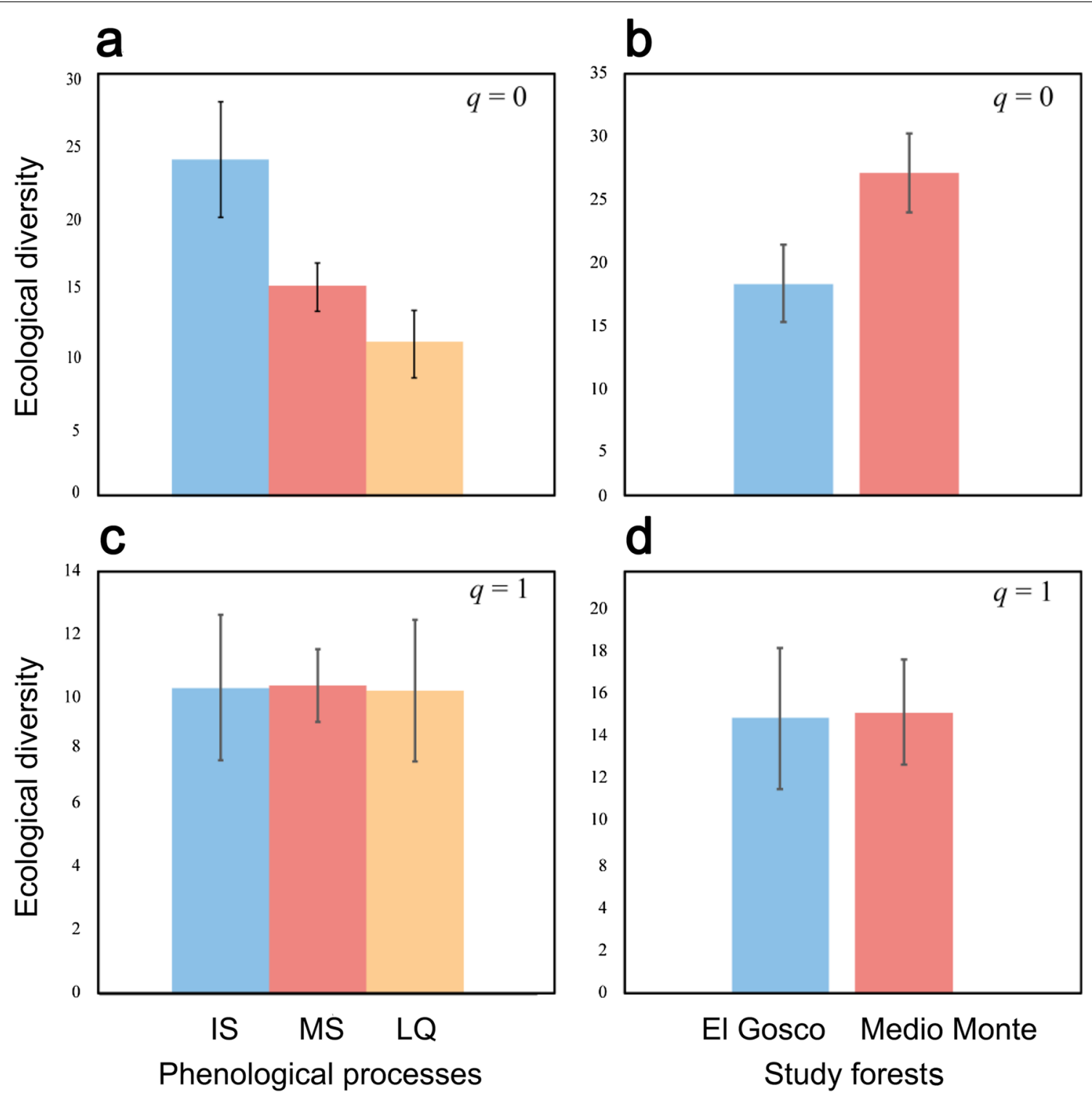

Fig. 5 Hill's numbers of species richness of avian communities ( $\mathbf{a}$ and $\mathbf{b}$ ) $q=0$ and ecological diversity (c and $\mathbf{d}$ ) $q=1$ during three phenological processes and in two fragmented forests, and $95 \%$ confidence intervals

( $q=1$; Fig. $5 \mathrm{~d}$ ). Our PERMANOVA analysis showed significant differences in avian communities' composition among three phenological processes (pseudo- $F=3.26$, $\mathrm{df}=2, P=0.05)$ and no differences between fragmented forests (pseudo- $F=1.64, \mathrm{df}=1, P=0.24$ ) were reflected in the NMDS ordination (Fig. 6).

\section{Beta diversity}

The shared complementarity index value was $86.6 \%$ between IS and MS, 92.3\% between MS and LQ, and 90.9\% between IS and LQ. We detected 15 exclusive avian species during IS, 7 species during MS, and 5 species during LQ (Fig. 7a). Between fragmented forests, the shared index value was $56 \%$, and 18 species were exclusive to Medio Monte and 8 to El Gosco (Fig. 7b).

The total average avian beta diversity $\left(\beta_{\mathrm{cc}}=0.78\right)$ between IS and MS was mainly explained by turnover $\left(\beta_{.3}=0.5\right)$ and followed by nestedness in a low proportion $\left(\beta_{\text {rich }}=0.28\right.$; Fig. $\left.8 \mathrm{a}\right)$. The same pattern existed between MS and LQ, where the total average beta was 0.81 , with high turnover $\left(\beta_{.3}=0.63\right)$ and low nestedness $\left(\beta_{\text {rich }}=0.18\right.$; Fig. 8a). Between IS and LQ, the total average beta was 0.83 , and the turnover and nestedness had similar values $\left(\beta_{.3}=0.40\right.$, and $\beta_{\text {rich }}=0.43$; Fig. 8a). 


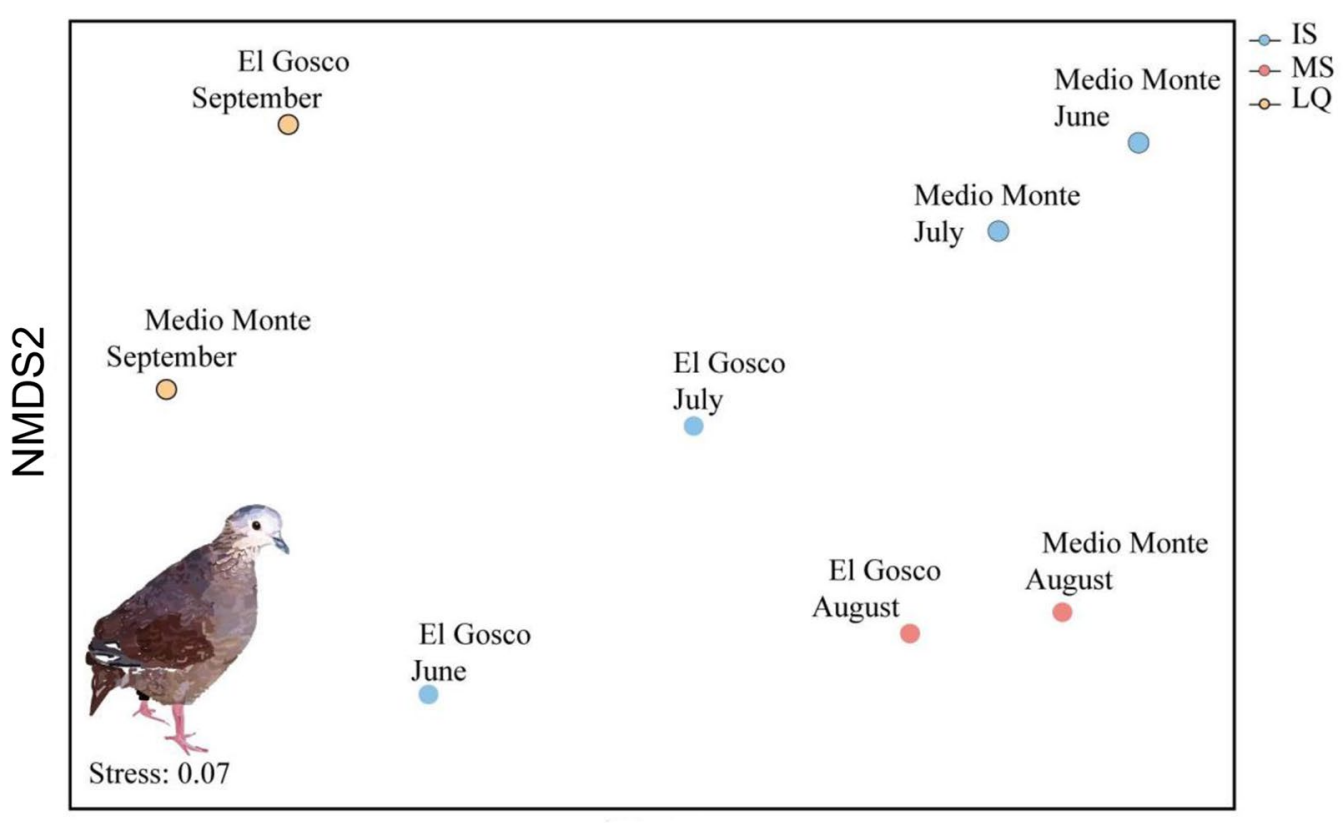

NMDS1

Fig. 6 Non-metric multidimensional scaling (NMDS) ordination based on avian richness during three phenological processes linked with fragmented forests

The total average avian beta diversity between fragmented forests $\left(\beta_{\mathrm{cc}}=0.70\right)$ was mainly explained by turnover $\left(\beta_{.3}=0.43\right)$ and followed by nestedness in a low proportion $\left(\beta_{\text {rich }}=0.27\right.$; Fig. $\left.8 \mathrm{~b}\right)$. Beta diversity during the LQ process was not assessed within each fragmented forest due to the limited data recorded (Table 2).

\section{Discussion}

Overall, our results showed that the phenological process influenced alpha and beta avian diversity values. Differences were also observed between the two fragmented forests. Alpha diversity showed differences in avian species richness $(q=0)$ among three phenological processes. During IS a higher species richness was registered, represented by dominant insectivorous-frugivorous species (e.g. Myadestes occidentalis, Trogon mexicanus, and Melanerpes formicivorus). In this process, beechnuts were immature or attacked by insects, and it is possible that these resources attracted those insectivorous birds that feed on them. Later, during the MS we observed dominance by granivorous-frugivorous species (e.g. Zentrygon albifacies and Pionus senilis) and the beechnuts were undamaged; probably the masting period influenced the presence of seed bird consumers and forced non-seed consumers to search for other resources. In the LQ process was registered lower species richness, dominated again by insectivorous species (i.e. Cyanolyca nana), and during this process, seeds were empty, so possibly the presence of insects became the most important resource.

When comparing fragmented forests, we found that the bigger, least-disturbed and better-connected fragment showed highest undamaged beechnut production (Medio Monte), which also showed a higher avian species richness than the severely fragmented forest (El Gosco) with a very low seed production. Previous study in the TMCF identified that the size of the fragment was the most important feature having a positive relationship with species richness; while the connectivity did not seem to influence the bird species richness (MartínezMorales 2005). Bird abundance patterns were similar among the three phenological processes and between forests, thus the beechnut presence had no influence on the number of bird individuals, a possible explanation could be related with found it by Martínez-Morales (2007) where generally the abundance distribution of bird community in the TMCF is given by a few bird species were very abundant and many species with scarce abundance, this pattern was reflected in the Fig. 4 where few bird species were dominant through phenological processes and between forests. However, other particular forest fragments features are needed to measure and evaluate the specific requirements of bird community, such as roosting and shelter sites, feeding, nesting and protection from predators could be influenced our results (Martínez-Morales 2005). Further studies related with 


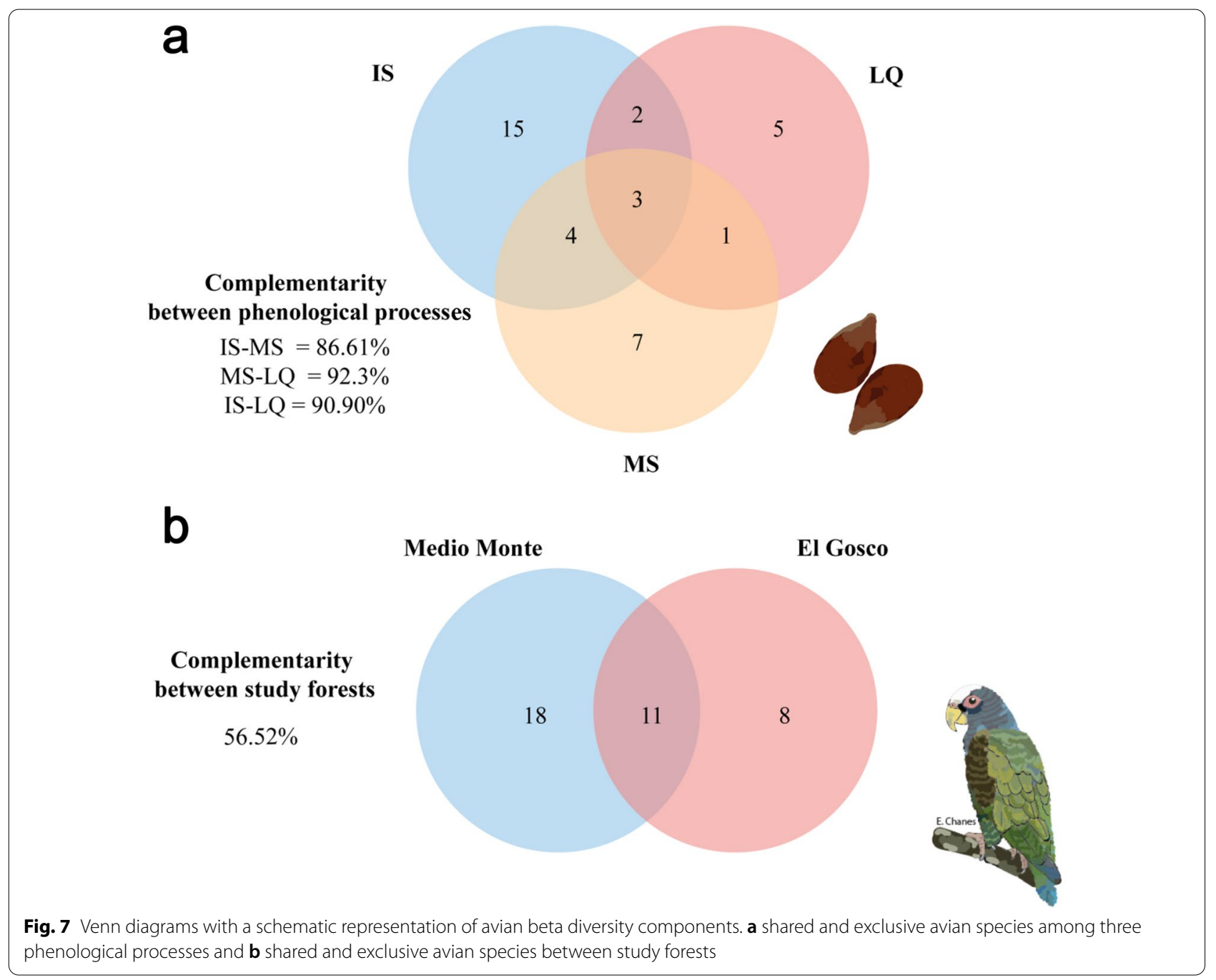

the bird species life-traits and specific measurements of microenviromental features in the Mexican Beech forests are necessary.

Our field observations confirm that the granivorousfrugivorous White-faced Quail-Dove and the Whitecrowned Parrot are potential Mexican beechnut-dispersal agents and/or predators. This is consistent with similar results reported by (Ehnis 1981) who addresses that parrots and other bird species visit the Mexican Beech forests only during masting. Several studies in American Beechnut (Fagus grandifolia) and Common Beechnut have highlighted the relevance of seed bird consumers, and their direct influence as dispersal and/or predators in the regeneration of those forests; for example, the nowextinct Passenger Pigeon (Ectopistes migratorius (Guiry et al. 2020), the Nutcracker (Nucifraga caryocatactes), the Blue Jay (Cyanocytta cristata), the Mallard (Anas platyrhynchos), the Common Wood Pigeon (Columba palumbus) and the Eurasian Jay (Garrulus glandarius) (Turcek and Kelso 1968; Darley-Hill and Johnson 1981). On the other hand, the Brambling (Fringilla montifringilla), the Eurasian Nuthatch (Sitta europaea), and the Marsh Tit (Poecile palustris) have been reported as short-distance dispersal agents (Nilsson 1985). During a masting event the Mexican Beech forest features trigger different responses for seed and non-seed bird consumers. For example, granivorous and frugivorous bird species are directly benefited, while insectivorous bird species could benefit indirectly by the presence of arthropods (i.e. insects, myriapods and arachnids; Wells et al. 2011), as well as other specific requirements of certain bird species, such as roosting areas, nesting grounds, and protection from predators (Martínez-Morales 2007).

Our results reflect the importance of the TMCFs and their tree communities (i.e. Mexican Beech forests) as refuges ("safe sites"; Reid 1991) for maintaining several endemic, threatened, and range-restricted bird species, as previous studies have established (Martínez-Morales 


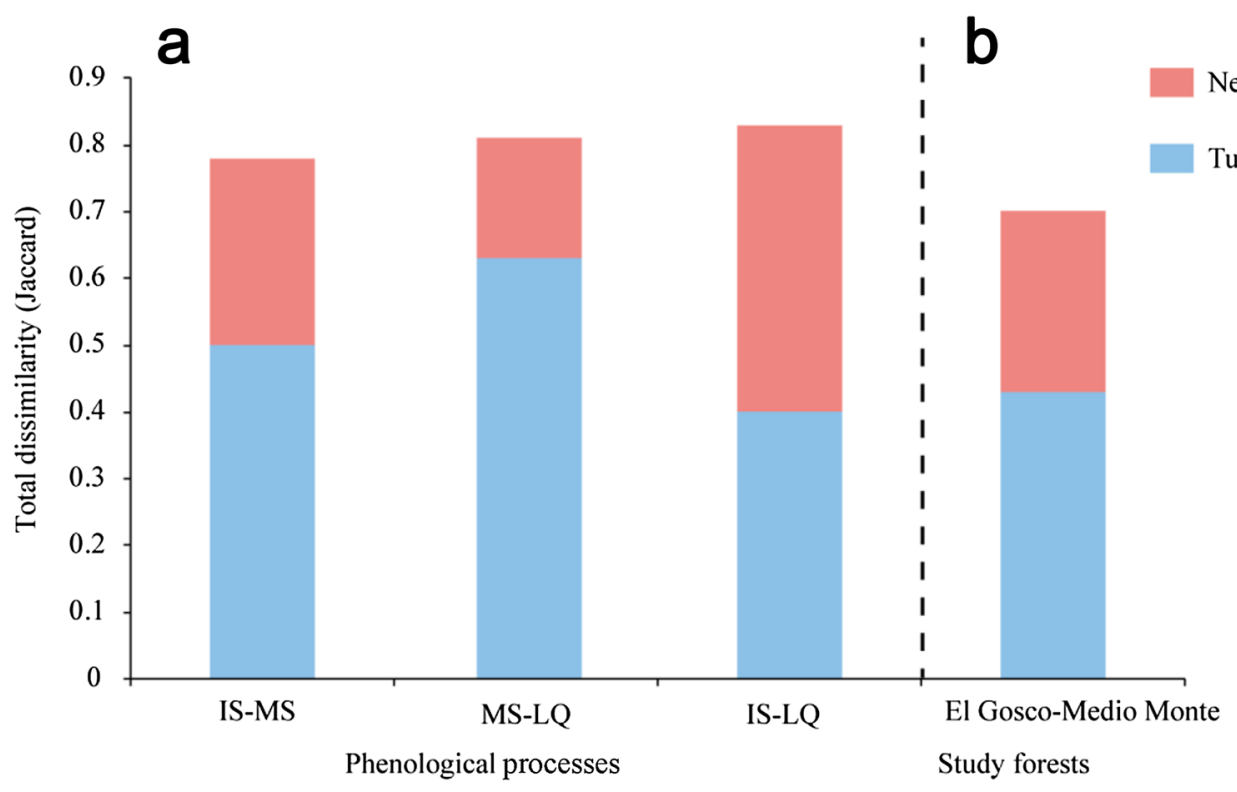

Fig. 8 Beta diversity and its components between pairs of a phenological processes and $\mathbf{b}$ Mexican Beech forests

2005, 2007; Navarro-Sigüenza et al. 2014; Rueda-Hernandez et al. 2015). For example, the Bearded WoodPartridge (Dendrortyx barbatus), the White-faced Quail-Dove, the Tawny-throated Leaftosser (Sclerurus mexicanus), the Spotted Woodcreeper (Xiphorhynchus erythropygius), the Brown-capped Vireo (Vireo leucophrys), the Dwarf Jay, the Grey-breasted Wood-Wren (Henicorhina leucophrys), and the Golden-browed Warbler (Basileuterus belli) are considered to be restricted to TMCF (Martínez-Morales 2005; Sánchez-González and Navarro-Sigüenza 2009).

In our study, we found a high bird species complementarity between phenological processes. For example, the highest value was between the MS-LQ, where only one exclusive species belonged to the granivorous-frugivorous-insectivorous guilds, followed by the IS-LQ process where two exclusive bird species belonged to the insectivorous and fructivorous-insectivorous guilds. The lowest value was between the IS-MS process, where four exclusive bird species belonged to the insectivorous, omnivorous, and fructivorous-insectivorous guilds. Between phenological processes a low interspecific competition can be expected, because food resources are better diversified (e.g. seeds and insects; Loreau 2000). Between fragmented forests, however, we found a medium bird species complementarity value where the exclusive species were represented by different trophic guilds; possibly increasing the interspecific competition by the limited food resources adding the contrast features between forests (e.g. logging, fragment size, isolation, and complex structure vegetation).

High turnover was detected in the transition between IS-MS and between MS-LQ, as well as between fragmented forests. These results are possibly related by the forest attributes (i.e. vegetation structure, topography, drizzle and/or fog) triggered that beechnuts production impacting the food resources available for some specific bird species (i.e. Zentrygon albifacies and Pionus senilis). Previously, Rueda-Hernandez et al. (2015) in the state of Veracruz, Mexico, Calderón-Patrón et al. (2016) in the state of Hidalgo, and Rahbek et al. (2019) worldwide reported a high avian turnover in the TMCFs, which was related to habitat heterogeneity. Meanwhile, in Europe the high avian turnover was associated with the Common Beech forest attributes and microclimatic conditions (Mentil et al. 2018).

Nevertheless, we found similar values of beta diversity components (turnover and nestedness) between IS-LQ showing that masting influenced a high dissimilarity in the avian community, but beechnut absence allowed both components of beta diversity to equally affect these assemblages. This phenomenon is related to the predator satiation hypothesis (Kelly 1994), which states that the presence of synchronous masting (seed production) will maximize the probability of satiating the seed consumer predators, allowing some seeds to germinate. Likewise, masting could influence avian species replacement, even though the responses depend on factors like mobility, life history and diet of seed predators (Bogdziewicz et al. 
2020). Therefore, our results supported the hypothesis regarding phenological process (IS, MS and LQ) influencing alpha and beta avian diversity and their trophic guilds composition during masting events, as well as in two contrasting Mexican Beech forests.

Particularly, inter-annual variation in plant reproduction (masting) of relict-endangered Mexican Beech forest depends on specific climatic conditions (e.g. temperature and/or precipitation; Rodríguez-Ramírez et al. 2018a, b). However, other studies (Téllez-Valdés et al. 2006) showed that climatic fluctuations and anthropogenic landscape changes (e.g. grazing, cattle, agricultural activity and mixed crops; Rodríguez-Ramírez et al. 2013) have possibly modified the synchronous process by an asynchronous one (Burns 2012) directly influencing the seed bird consumers and, indirectly, the non-seed bird consumers (Grendelmeier et al. 2019) modifying the ecological interaction within forests. Future studies are necessary, for example to: (1) assessing ex situ the effect of White-faced Quail-Dove, White-crowned Parrot or other resident bird species can be considered beechnut dispersers, seed consumers or non-seed consumers; (2) evaluate beechnut quality among Mexican Beech fragments; and (3) relate bird diversity with masting years versus non-masting year.

\section{Conclusions}

Our results are the first evidence that shows that masting phenological process influences the bird species richness and turnover in relict-endangered Mexican Beech forests, but not abundance patterns, the same tendency was found in contrasting Mexican Beech fragmented forests. In accordance to Rodríguez-Ramírez et al. (2013) and Téllez-Valdés et al. (2006), Mexican Beech forests are a good model to identify priority areas for conservation in the TMCF, due to its restricted distribution and high biological value (e.g. high species richness, endemisms and presence of endangered species). Finally, it is imperative to address regional conservation efforts to preserve this threatened ecosystem due to constant anthropogenic pressure.

\section{Acknowledgements}

We wish to thank I. Zuria for her valuable comments to improve this manuscript. We thank Mary-Ann Hall and I. Zuria for checking the language of this manuscript.

\section{Authors' contributions}

ECR-R: conceptualization, methodology, investigation, writing, review and editing. LC-I, APM-F: methodology, writing, review and editing. IL-V: writing, review and editing. PC-R: conceptualization, supervision, methodology, writing, review and editing. All authors read and approved the final manuscript.

\section{Funding}

The first author also acknowledges the financial support granted by the postdoctoral fellowship CONACYT 2019-2020. This research was funded by the DGAPA PAPIIT IN220621 project.
Availability of data and materials

The datasets used in the present study are available from the corresponding author on reasonable request.

\section{Declarations}

Ethics approval and consent to participate

Not applicable.

\section{Consent for publication \\ Not applicable.}

\section{Competing interests}

The authors declare that they have no competing interests.

\section{Author details}

${ }^{1}$ Laboratorio de Dendrocronología, Universidad Continental, Huancayo, Perú. ${ }^{2}$ Laboratorio de Biogeografía y Sistemática, Universidad Nacional Autonoma de México, Ciudad de México, Mexico. ${ }^{3}$ Centro de Investigaciones Biológicas, Universidad Autónoma de Estado de Hidalgo, Hidalgo, Mexico. ${ }^{4}$ Independent Researcher, Oulu, Finland.

Received: 23 March 2021 Accepted: 22 September 2021

Published online: 04 October 2021

\section{References}

Amico GC, Aizen MA. Dispersión de semillas por aves en un bosque templado de Sudamérica austral: ¿quién dispersa a quién? Ecol Aust. 2005;15:89-100.

Baselga A. Partitioning the turnover and nestedness components of beta diversity. Global Ecol Biogeogr. 2010;19:134-43.

Billerman SM, Keeney BK, Rodewald PG, Schulenberg TS. Birds of the world. Cornell Lab Ornithology. 2020. https://birdsoftheworld.org/bow/home.

Bogdziewicz M, Kelly D, Thomas PA, Lageard JGA, Hacket-Pain A. Climate warming disrupts mast seeding and its fitness benefits in European Beech. Nat Plants. 2020;6:88-94.

Burns KC. Masting in a temperate tree: evidence for environmental prediction? Austral Ecol. 2012;37:175-82.

Calderón-Patrón JM, Goyenechea I, Ortiz-Pulido R, Castillo-Cerón J, Manriquez N, Ramírez-Bautista A, et al. Beta diversity in a highly heterogeneous area: disentangling species and taxonomic dissimilarity for terrestrial vertebrates. PLoS ONE. 2016;11:e0160438.

Carvalho JC, Cardoso P, Gomes P. Determining the relative roles of species replacement and species richness differences in generating beta-diversity patterns. Global Ecol Biogeogr. 2012;21:760-71.

Carvalho JC, Cardoso P, Borges PAV, Schmera D, Podani J. Measuring fractions of beta diversity and their relationships to nestedness: a theoretical and empirical comparison of novel approaches. Oikos. 2013;122:825-34.

Chamberlain DE, Gosler AG, Glue DE. Effects of the winter beechmast crop on bird occurrence in British gardens. Bird Study. 2007;54:120-6.

Chao A, Gotelli NJ, Hsieh TC, Sander EL, Ma KH, Colwell RK, et al. Rarefaction and extrapolation with Hill numbers: a framework for sampling and estimation in species diversity studies. Ecol Monogr. 2014;84:45-67.

Chao A, Jost L. Coverage-based rarefaction and extrapolation: standardizing samples by completeness rather than size. Ecology. 2012;93:2533-47.

Chesser RT, Burns KJ, Cicero C, Dunn JL, Kratter AW, Lovette IJ, et al. Check-list of North American birds. American Ornithological Society. 2019. http:// checklist.aou.org/taxa.

Clarke KR. Non-parametric multivariate analyses of changes in community structure. Aust J Ecol. 1993;18:117-43.

Colwell RK, Coddington JA. Estimating terrestrial biodiversity through extrapolation. Phil Trans R Soc Lond b. 1994;345:101-18.

Darley-Hill S, Johnson WC. Acorn dispersal by the blue jay (Cyanocitta cristata). Oecologia. 1981;50:231-2.

Ehnis DA. Fagus mexicana Martínez, su ecología e importancia. Doctoral Thesis. Mexico City: Universidad Autónoma de México; 1981.

Fletcher MS. Mast seeding and the El Niño-Southern Oscillation: a long-term relationship? Plant Ecol. 2015;216:527-33. 
Godínez-Ibarra O, Ángeles-Pérez G, López-Mata L, García-Moya E, ValdezHernández Jl, de Los Santos-Posadas H, et al. Seed rain and seedling emergence of Fagus grandifolia subsp. mexicana at La Mojonera, Hidalgo. Mexico Rev Mex Biodiv. 2007;78:117-28.

Grendelmeier A, Flade M, Pasinelli G. Trophic consequences of mast seeding for avian and mammalian seed and non-seed consumers in European temperate forests. J Ornithol. 2019;160:641-53.

Gual-Díaz M, Rendón-Correa A. Bosques mesófilos de montaña de México diversidad, ecología y manejo. In: Gual-Díaz M, Rendón-Correa A, editors. Bosques mesófilos de montaña de México diversidad, ecología y manejo. 1st ed. Mexico: CONABIO; 2014. p. 27-67.

Guiry EJ, Orchard TJ, Royle TCA, Cheung C, Yang DY. Dietary plasticity and the extinction of the passenger pigeon (Ectopistes migratorius). Quaternary Sci Rev. 2020;233:106225.

Hagen M, Kissling WD, Rasmussen C, de Aguiar MA, Brown LE, Carstensen DW, et al. Biodiversity, species interactions and ecological networks in a fragmented world. Adv Ecol Res. 2012;46:89-210.

Hill MO. Diversity and evenness: a unifying notation and its consequences. Ecology. 1973;54:427-32.

Howell SNG, Webb S. A guide to the birds of Mexico and northern central America. England: Oxford University Press; 1995.

$\mathrm{Hu}$ J, Riveros-Iregui DA. Life in the clouds: are tropical montane cloud forests responding to changes in climate? Oecologia. 2016;180:1061-73.

Jansen PA, Bongers F, Hemerik L. Seed mass and mast seeding enhance dispersal by a Neotropical scatter-hoarding rodent. Ecological Monographs Ecol Soc Am. 2004;74:569-89.

Jensen TS. Seed-seed predator interactions of European Beech, Fagus sylvatica and forest rodents, Clethrionomys glareolus and Apodemus flavicollis. Oikos. 1985;44:149-56.

Jost L. Entropy and diversity. Oikos. 2006;113:363-75.

Kardell L. Bokens spridning I Trogds harad. Sartryck Ur Lustgarden. 2005:85:29-44.

Kelly D. The evolutionary ecology of mast seeding. Trends Ecol Evol. 1994;9:465-70.

Kottek M, Grieser J, Beck C, Rudolf B, Rubel F. World Map of the Köppen-Geiger climate classification updated. Meteorol Z. 2006:15:259-63.

Loreau M. Biodiversity and ecosystem functioning: recent theoretical advances. Oikos. 2000;91:3-17.

Luna-Vega I, Alcántara-Ayala O, Morrone JJ, Espinosa-Organista D. Track analysis and conservation priorities in the cloud forests of Hidalgo. Mexico Divers Distrib. 2000;6:137-43.

Magurran AE. Measuring biological diversity. Malden, MA: Blackwell Science Ltd.; 2004.

Martínez-Morales MA. Nested species assemblages as a tool to detect sensitivity to forest fragmentation: the case of cloud forest birds. Oikos. 2005; 108:634-42.

Martínez-Morales MA. Avifauna del bosque mesófilo de montaña del noreste de Hidalgo. México Rev Mex Biodiv. 2007;78:149-62.

Mentil L, Battisti C, Maria CG. The older the richer: significant increase in breeding bird diversity along an age gradient of different coppiced woods. Web Ecol. 2018;18:143-51.

Mulligan M. Modelling the tropics-wide extent and distribution of cloud forest and cloud forest loss, with implications for conservation priority. In: Bruijnzeel LA, Scatena FN, Hamilton LS, editors. Tropical montane cloud forests: science for conservation and management. Cambridge: Cambridge University Press; 2010. p. 14-38.

Muñoz-Villers LE, López-Blanco J. Land use/cover changes using Landsat TM/ ETM images in a tropical and biodiverse mountainous area of central eastern Mexico. Int J Remote Sens. 2008;29:71-93.

National Geographic Society. Field guide to the birds of North America. Washington: National Geographic Society; 2006

Navarro-Sigüenza AG, Rebón-Gallardo MF, Gordillo-Martínez A, Peterson AT, Berlanga- García H, Sánchez-González LA. Biodiversity of birds in Mexico. Rev Mex Biodiv. 2014:85:476-95.

Nilsson SG. Ecological and evolutionary interactions between reproduction of beech Fagus sylvatica and seed eating animals. Oikos. 1985:44:157-64.

Oksanen J, Guillaume-Blanchet F, Friendly M, Kindt R, Legendre P, McGlinn D, et al. vegan: community ecology package. R package version 2.5-6. 2019 https://CRAN.R-project.org/package=vegan.
Olvera-Vital A, Rebón-Gallardo MF, Navarro-Sigüenza AG. Bird diversity and taxonomic turnover in the different habitats in Misantla, Veracruz, Mexico: species comparison over time. Rev Mex Biodiv. 2020;91:e913070.

Pearse IS, Koenig WD, Kelly D. Mechanisms of mast seeding: resources, weather, cues, and selection. New Phytol. 2016;212:546-62.

Peel MC, Finlayson BL, McMahon TA. Updated world map of the KöppenGeiger climate classification. Hydrol Earth Syst Sci. 2007;11:1633-44.

Perdeck AC, Visser ME, van Balen JH. Great tit Parus major survival, and the beech-crop cycle. Ardea. 2000;88:99-106.

Pérez-Rodríguez PM. Las hayas de México, monografía de Fagus grandifolia spp. mexicana. 1st ed. Texcoco: Universidad Autónoma de Chapingo; 1999.

Peterson TR, Edward FC. Aves de México: Guía de Campo, identificación de otras especies encontradas de México, Guatemala, Belice y El Salvador. Mexico City: Editorial Diana; 1989

Podani J, Schmera D. A new conceptual and methodological framework for exploring and explaining pattern in presence - absence data. Oikos 2011:120:1625-38.

Ponce-Reyes R, Reynoso-Rosales VH, Watson JEM, VanDerWal J, Fuller RA, Pressey RL, et al. Vulnerability of cloud forest reserves in Mexico to climate change. Nat Clim Change. 2012;2:448-52.

R Core Team. R: a language and environment for statistical computing (version 3.4.3). R Foundation for Statistical Computing; 2018. https://www.r-proje ct.org/.

Rahbek C, Borregaard MK, Colwell RK, Dalsgaard B, Holt BG, Morueta-Holme $\mathrm{N}$, et al. Humboldt's enigma: what causes global patterns of mountain biodiversity? Science. 2019:365:1108-13.

Ralph CJ, Geupel GR, Pyle P, Martin TE, DeSante DF, Milá B. Manual de métodos de campo para el monitoreo de aves terrestres. Albany: Pacific Southwest Research Station, Forest Service, U.S. Department of Agriculture; 1996.

Reid N. Coevolution of mistletoes and frugivorous birds? Aust J Ecol. 1991;16:457-69.

Rodríguez-Ramírez EC, Luna-Vega I, Rozas V. Tree-ring research of Mexican Beech (Fagus grandifolia subsp. mexicana) a relict tree endemic to eastern Mexico. Tree-Ring Res. 2018a;74:94-107.

Rodríguez-Ramírez EC, Sánchez-González A, Ángeles-Pérez G. Relationship between vegetation structure and microenvironment in Fagus grandifolia subsp. mexicana forest relicts in Mexico. J Plant Ecol. 2018b;11:237-47.

Rodríguez-Ramírez EC, Sánchez-González A, Ángeles-Pérez G. Current distribution and coverage of Mexican Beech forests Fagus grandifolia subsp. mexicana in Mexico. Endang Species Res. 2013;20:205-16.

Rodríguez-Ramírez EC, Terrazas T, Luna-Vega I. The influence of climate on the masting behavior of Mexican Beech: growth rings and xylem anatomy. Trees. 2019;33:23-35.

Rosemier JN, Flaspohler DJ. Island-specific ecological release of small mammals in Lake Michigan and potential consequences for ground-nesting birds: The importance of American Beech (Fagus grandifolia) in structuring small-mammal communities. George Wright Soc. 2006;23:24-32.

Rueda-Hernandez R, MacGregor-Fors I, Renton K. Shifts in resident bird communities associated with cloud forest patch size in Central Veracruz. Mexico Avian Conserv Ecol. 2015:10:2

Roman L, Scatena FN, Bruijnzeel LA. Global and local variations in tropical montane cloud forest soils. In: Bruijnzeel LA, Scatena FN, Hamilton LS, editors. Tropical montane cloud forests: science for conservation and management. Cambridge: Cambridge University Press; 2010. p. 77-89.

Sánchez-González LA, Navarro-Sigüenza AG. History meets ecology: a geographical analysis of ecological restriction in the Neotropical humid montane forests avifaunas. Divers Distrib. 2009;15:1-11.

SEMARNAT. SEMARNAT-Secretaría de Medio Ambiente y Recursos Naturales. Diario Oficial. 2010.

Téllez-Valdés O, Dávila-Aranda P, Lira-Saade R. The effects of climate change on the long-term conservation of Fagus grandifolia var. mexicana, an important species of the cloud forest in eastern Mexico. Biodivers Conserv. 2006:15:1095-107.

Toledo-Aceves T, Meave JA, González-Espinosa M, Ramírez-Marcial N. Tropical montane cloud forests: current threats and opportunities for their conservation and sustainable management in Mexico. J Environ Manage. 2011;92:974-81.

Turcek F, Kelso L. Ecological aspects of food transportation and storage in the Corvidae. Commun Behav Biol Part a. 1968:1:277-97. 
van Perlo B. Birds of Mexico and Central America. Princeton: Princeton University Press; 2006.

Wells K, Böhm SM, Boch S, Fischer M, Kalko EKV. Local and landscape-scale forest attributes differ in their impact on bird assemblages across years in forest production landscapes. Basic Appl Ecol. 2011;12:97-106.

Williams-Linera G, Rowden A, Newton AC. Distribution and stand characteristics of relict populations of Mexican Beech (Fagus grandifolia var. mexicana). Biol Conserv. 2003;109:27-36

Yasaka M, Terazawa K, Koyama H, Kon H. Masting behavior of Fagus crenata in northern Japan: spatial synchrony and pre-dispersal seed predation. Forest Ecol Manage. 2003;184:277-84.
Yui M. Animals of beech forests. In: Murai H, Yamatani K, Kataoka H, Yui M, editors. Natural environment and its conservation on Buna (Fagus crenata) forest. Tokyo: Soft Science Inc.; 1991. p. 193-234 (in Japanese).

Zaccagnini ME, Thompson JJ, Bernardos JN, Calamari NC, Goijman AP, Canavelli SB. Riqueza, ocupación y roles funcionales potenciales de las aves en relación a los usos de la tierra y la productividad de los agroecosistemas: un ejemplo en la ecoregion pampeana. In: Laterra P, Jobbágy EG, Paruelo JM, editors. Valoración de servicios ecosistémicos: conceptos, herramientas y aplicaciones para el ordenamiento territorial. Chapter: 8. Buenos Aires: Ediciones inta. 2011. p. 185-219.
Ready to submit your research? Choose BMC and benefit from:

- fast, convenient online submission

- thorough peer review by experienced researchers in your field

- rapid publication on acceptance

- support for research data, including large and complex data types

- gold Open Access which fosters wider collaboration and increased citations

- maximum visibility for your research: over $100 \mathrm{M}$ website views per year

At BMC, research is always in progress.

Learn more biomedcentral.com/submissions 